\title{
Article/Artigo
}

\section{Serosurvey of hantavirus infection in humans in the border region between Brazil and Argentina}

\author{
Estudo sorológico de infecção por hantavírus em humanos na região de fronteira, entre Brasil \\ e Argentina
}

\section{William Marciel de Souza ${ }^{1}$, Alex Martins Machado ${ }^{1}$, Luiz Tadeu Moraes Figueiredo ${ }^{1}$ and Everton Boff ${ }^{2}$}

\begin{abstract}
Introduction: According to reports by the Ministry of Health, in the far western region of the State of Santa Catarina, there have been no reports of hantavirus pulmonary syndrome, a zoonotic disease transmitted by feces of infected rodents. A seroepidemiological study of residents of this region, was conducted, with the aim of determining the presence of hantavirus infections. A total of 340 volunteers of both genus, from the towns of Belmonte and Paraíso, were studied. Methods: The serum of these patients was collected and used to detect $\operatorname{IgG}$ antibodies against recombinant $\mathrm{N}$ protein of Araraquara hantavirus, by ELISA assay. The positive samples were then titrated and confirmed by immunofluorescence assay. Results: This study demonstrated the presence of IgG antibodies against hantavirus $\mathrm{N}$ protein in $3.5 \%$ of the population. The most frequent occupation was farm worker, $81 \%$ had direct and indirect contact with rodents, $91.7 \%$ of positive cases were farm workers, indicating that the probable cause of infection occurred during barn cleaning. These antibodies are noteworthy, given that the levels of antibodies were verified in individuals whose contact with hantavirus may have occurred many years ago. Conclusions: This study shows the circulation of hantavirus in the region, a fact that until now, had not reported. All the serum reagents had contact with the pathogen, but did not develop pulmonary and cardiovascular syndrome. It is important to remain alert, because hantavirus is a serious and emerging disease of some relevance.
\end{abstract}

Keywords: Hantavirus. Seroprevalence in Santa Catarina. Morbidity.

\section{RESUMO}

Introdução: De acordo com relatórios do Ministério da Saúde, na região do extremo oeste do Estado de Santa Catarina, não há relatos de síndrome pulmonar por hantavírus, doença zoonótica transmitida por excretas de roedores contaminados. Com a finalidade de demosntrar a infecção por hantavírus, um estudo soroepidemiológico de moradores da região foi realizado. Assim, foi estudado um total de 340 voluntários de ambos os gêneros, dos municípios de Belmonte e Paraíso. Métodos: O soro destes pacientes foi coletado e usado para a detecção de anticorpos IgG contra a proteína $\mathrm{N}$ recombinante de hantavírus Araraquara, pelo teste de ELISA. As amostras positivas foram tituladas e confirmadas por imunofluorescência indireta. Resultados: Este estudo demonstrou a presença de anticorpos IgG contra a proteína $\mathrm{N}$ hantavírus em 3,5\% da população. A ocupação de lavrador foi a mais frequente, e $81 \%$ tiveram contato direto e indireto com os roedores, $91,7 \%$ dos casos positivos foram os agricultores, a causa provável da infecção foi através da limpeza de celeiros. Estes anticorpos são notáveis, dado que os níveis de anticorpos são encontrados nos indivíduos cujo contato com o hantavírus pode ter ocorrido há muitos anos. Conclusões: Este estudo mostra a circulação de hantavírus na região, um fato que até então não havia relatado, todos os reagentes soro tiveram contato com o patógeno, mas não desenvolveram a síndrome pulmonar e cardiovascular. É preciso estar alerta, porque é uma doença grave e emergente com grande importância.

Palavras-chaves: Hantavírus. Soroprevalência de hantavirose em Santa Catarina. Morbidade.

1. Centro de Pesquisa em Virologia, Faculdade de Medicina, Universidade de São Paulo, Ribeirão Preto, SP. 2. Departamento de Ciências Biológicas e da Saúde, Universidade do Oeste de Santa Catarina, São Miguel do Oeste, SC.

Address to: Dr. William Marciel de Souza. Centro de Pesquisa em Virologia/FM/USP. Av Bandeirantes 3900, 14049-900 Ribeirão Preto, SP, Brasil.

Phone: $55163289-7646$

email: wmarciel@hotmail.com

Received in 30/03/2010

Accepted in 16/11/2010

\section{INTRODUCTION}

Viruses of the genus hantavirus can cause two serious illnesses when transmitted from rodents to humans: hemorrhagic fever with renal syndrome (HFSR) or hantavirus pulmonary syndrome (HPS), characterized by respiratory failure, shock and high mortality, making it an important public health problem ${ }^{1}$.

Hantavirus is an enveloped virus with trisegmented negative sense RNA genome, defined as small, medium and large. Human infection is acquired by inhalation of aerosols containing excreta of rodents infected with hantavirus; i.e., infected by a virus of the family Bunyaviridae ${ }^{2}$, which includes than 20 hantaviruses identified throughout the American continent ${ }^{3}$.

Interpersonal transmission of hantavirus has been reported only in Argentina and Chile, but further investigation indicated that this possibility is very unlikely ${ }^{4-6}$. The contact with hantavirus in and of itself does not cause HPS, since infection is dependent on the quantity of viral particles, such that lower concentrations of particles could lead to subclinical infection. However, another possibility is infection by a nonpathogenic strain that induces immune response activation with antibody production $^{3,7}$.

The pathogenesis of HPS in humans is hypothesized to be mediated by immune activation and excess inflammatory responses, especially macrophages and CD $8+\mathrm{T}$ cells ${ }^{3}$. Excess cytokines IL-1- $\alpha$, IL-1- $\beta$, IL-6 and TNF- $\alpha$ interferon- $\gamma$, IL-2, IL- 4 and TNF- $\beta$ produced by activated macrophages in hantaviruses, specific $\mathrm{T}$ cells in recognition antigen infected pulmonary endothelial cells, are thought to be critical due to the increased permeability in the pathogenesis of HPS ${ }^{8}$.

Despite the severity of HPS, cases of human infection with mild forms of hantavirus without respiratory failure do occur; however the causes and factors involved in clinical behavior remain unknown?. 
Numerous diagnostic methods for these viruses have been produced, among these, the production of recombinant proteins, which are used as antigen in ELISA to enable detection of specific antibodies against this virus, should be highlighted ${ }^{10,11}$.

In South America, hantaviruses have been reported in Argentina, Chile, Uruguay, Paraguay, Bolivia and Venezuela ${ }^{12}$. In Brazil, the first evidence that this virus was circulating was observed in the study of three individuals living in a rural area of Juquitiba, São Paulo, in $1993^{13}$. Today, over 1,200 cases of hantavirus pulmonary syndrome have occurred in Brazil since 1993, fatalities were reported at a rate of $39 \%$, according to geographic and ethnic differences ${ }^{14}$. Five hantaviruses associated with HPS are currently known in Brazil: the Juquitiba, Araraquara, Laguna Negra-like, Castelo dos Sonhos and Anajatuba viruses ${ }^{15}$.

The first confirmed case of hantavirus in Santa Catarina was in 1999 and up to 2009, 205 cases have been confirmed. The first death from hantavirus in the state was reported in 2001 and 48 deaths have been reported up to the present, making this the state with the second highest death rate ${ }^{16}$. HPS is an emerging public health problem in Brazil due to the overlap of urban and agricultural areas, livestock and the disorderly growth of human population in areas where imbalance occurs, which increases human contact with several species of rodents that are reservoirs of hantavirus ${ }^{15}$. This study was conducted to investigate the presence of antibodies against hantavirus in the far western region of the State of Santa Catarina and the southern border of Brazil and northern Argentina and correlate this presence through interviews to elucidate the medical history and morbidity of the participants.

The study region has an economic base that comes from agricultural activities and accordingly, the degrading of native forest has occurred throughout the region, which is favorable to colonization by wild rodents. The study revealed the presence of

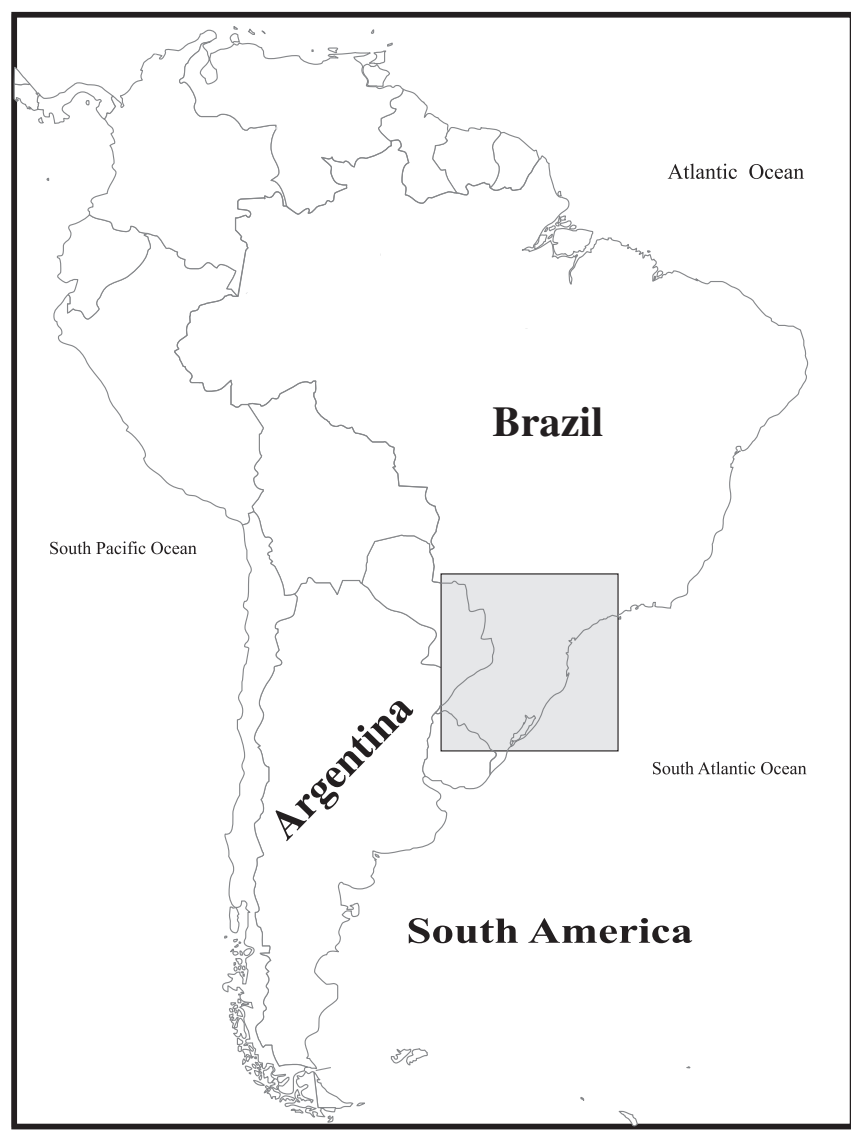

Necromys lasiurus and Oryzomys nigripes in the region, which are known rodent reservoirs of hantavirus, suggesting there is a chance of viral circulation and, therefore, risk of human infection ${ }^{17}$.

Although Santa Catarina is the state with the second d highest number of HPS cases, no cases of the disease have been recorded in the far west of the state ${ }^{16}$ or in municipalities in the study area that borders northeastern Argentina; however, previous studies have shown that the region has high numbers of HPS ${ }^{18}$.

Thus, it is unclear whether the lack of notification of hantavirus disease in this region is due, in fact, the absence of local disease or that infections occur and diagnosis is negligent. So far, no accurate survey of the presence of hantavirus has been conducted in the far west of Santa Catarina. Diagnostic tests to detect hantaviruses are only performed following clinical suspicion during hospital attendance, which is not common in the region.

The serological survey aimed to assess, for the first time, current results and scientific evidence of the absence or circulation of hantavirus in the far west of the state by helping to clarify the real situation of the virus in the region.

\section{METHODS}

\section{Study area}

The towns of Belmonte and Paraíso have respective populations of 2,681 and 4,195 inhabitants, who are mostly descended from Italians, Germans and Poles. They have a mesothermal humid climate, with hot summers and an average temperature of $18.3^{\circ} \mathrm{C}$, with the main economic activity based on agriculture, particularly the cultivation of monocultures of corn, wheat, tobacco and, consequently, a large part of the native forest has suffered degradation (Figure 1).

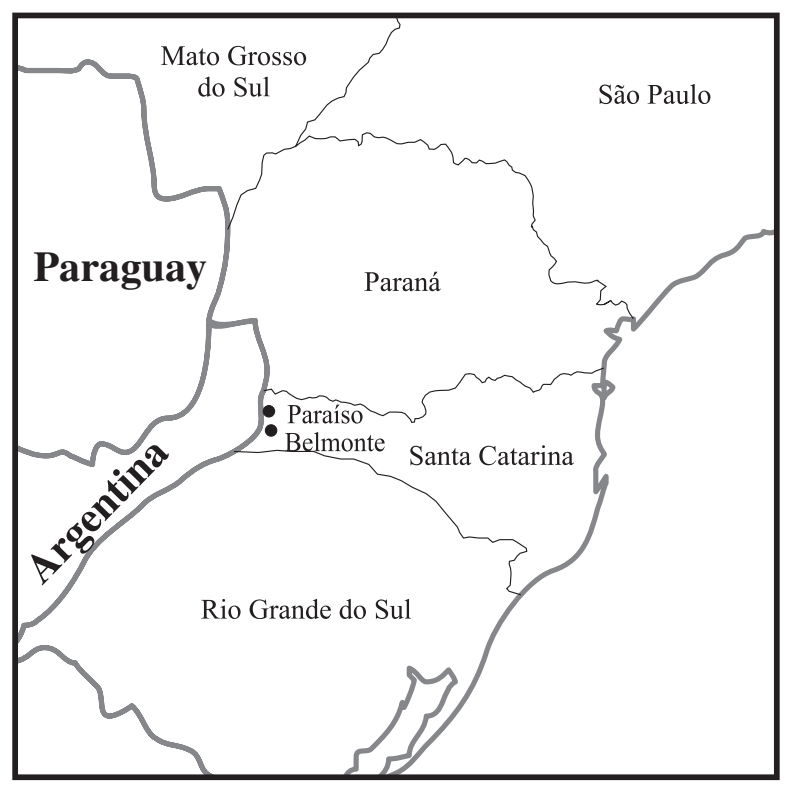

FIGURE 1 - Localization of study area Belmonte and Paraíso County. 


\section{Human samples}

Prior statistical analysis determined the calculation of a proportional stratified sample of the population; thus, a total of 340 volunteers of both sexes, aged between 18 and 90 years-old in December (summer) 2009, permitted the collection of blood samples.

\section{Immunoassay}

The blood samples were subjected to centrifugation to extract the serum, which were subjected to enzyme linked immunosorbent assay (ELISA) using as antigen a recombinant $\mathrm{N}$ protein of Araraquara hantavirus produced in E. coli. The samples were tested in duplicate, using a known sample positive for hantavirus Araraquara as the positive control and as the negative control, a protein extract of E. coli not containing the plasmid encoding the recombinant protein, according to the protocol developed by Figueiredo 2009 (Evaluation of an ELISA using rNucleoprotein of Araquarara). Following the test, the samples considered positive were then titrated. To achieve this, the sera were subjected to serial dilution of $1: 100$ to $1: 12,800$. These dilutions were retested in ELISA to determine the concentration of IgG anti-hantavirus in each of the serum.

\section{Immunofluorescence}

As a confirmatory test, positive sera in ELISA and titrated by the same method were submitted to indirect immunofluorescence assay (IFA) using cells infected with Rio Mamoré hantavirus and prefixed in spot slides for IFA, as described by Leduc ${ }^{19}$. The sera were then added to each of the spots. To determine the presence or absence of IgG anti-hantavirus, the sera were tested in a second antibody antihuman IgG labeled with the fluorochrome FITC and then observed under a fluorescent microscope. Positive and negative controls were performed using sera with or without anti-hantavirus antibodies.

\section{Ethical considerations}

The study was reviewed and approved by the Research Ethics Committee, in accordance with Ministry of Health protocol $n^{\circ} .073 / 2009$. Free informed consent was obtained from all patients, and the information was kept confidential.

\section{RESULTS}

A total of 340 volunteers with no prior history of hantaviruses were studied, residents of the microregion of the far west of the State of Santa Catarina, from the towns of Belmonte and Paraíso, on the Brazilian border with the Province of Misiones of the Republic of Argentina. Of these, $52.7 \%$ were men and $47.3 \%$ were women. Regarding the occupation of the respondents, $96 \%$ were directly related to the agricultural system and the occupation of farm worker was the most frequent with $85 \%$.

Among those interviewed, $80 \%$ reported storing food in barns and sheds (grain and tobacco) and at these sites and in the surrounding areas, $81 \%$ reported visual or physical contact with rodents. The procedure for cleaning these sites included sweeping and raking in $75.9 \%$. In houses, $64.3 \%$ said there was no garbage collection, such that this accumulated and was then incinerated, a practice that could attract rodents, thus increasing possible contact with hantavirus.

In enzyme immunoassays, 12 samples were seroreactive for the presence of $\operatorname{IgG}$ antibodies against $\mathrm{N}$ protein of hantaviruses, determining a prevalence of $3.5 \%$ of these antibodies in the population studied, while quantitative analysis, involving titration of positive sera, showed evidence of variation of up to $1: 2001: 6,400$. Sera positive for hantavirus by ELISA were confirmed by IFA.

Regarding medical history of morbidity presented by individuals who were positive for hantavirus, these patients reported the following symptoms: fever over $38^{\circ} \mathrm{C}$ for several days (33.3\%), dyspnea (25\%) and nasal bleeding (16.6\%), though the symptoms evolved to cure in a few days without medical intervention or hospitalization (Table 1). Although these symptoms are common in HPS, they are not very specific and the events cited by respondents cannot be directly linked to any disease or infection, since few responded with certainty regarding the moment of contact and any subsequent production of IgG antibodies against hantavirus.

TABLE 1 - Cases of hantavirus serology reagents according to gender, occupation, city, title and symptoms.

\begin{tabular}{lccccc}
\hline Genus & Age & Occupation & City & Title & Symptoms \\
\hline Male & 86 & farming & Paraíso & $1: 800$ & dyspnea \\
\hline Female & 27 & farming & Paraíso & $1: 6400$ & asymptomatic \\
\hline Female & 76 & farming & Paraíso & $1: 800$ & fever ${ }^{*} /$ dyspnea \\
\hline Male & 69 & farming & Paraíso & $1: 600$ & fever ${ }^{*} /$ dyspnea \\
\hline Male & 48 & farming & Paraíso & $1: 1600$ & nosebleed \\
\hline Female & 56 & farming & Paraíso & $1: 800$ & asymptomatic \\
\hline Female & 57 & farming & Paraíso & $1: 200$ & fever ${ }^{*} /$ dyspnea \\
\hline Male & 48 & farming & Paraíso & $1: 200$ & dyspnea \\
\hline Male & 56 & farming & Belmonte & $1: 1600$ & asymptomatic \\
\hline Female & 50 & farming & Belmonte & $1: 200$ & fever* \\
\hline Female & 18 & student & Belmonte & $1: 200$ & fever $/$ nosebleed \\
\hline Female & 27 & farming & Belmonte & $1: 200$ & asymptomatic \\
\hline
\end{tabular}

${ }^{*}$ Fever over $38^{\circ} \mathrm{C}$ lasting for several days.

\section{DISCUSSION}

Evidence of the presence of hantavirus in Brazil have been observed since the 1970's, initially isolated in Brazil in the State of Pará in Rattus norvegicus in the 1980' ${ }^{19}$. At this time showed, the presence of antibodies to Hantaan virus was also observed, the prototype of the genus hantavirus in rodent sera in the cities of Belém, São Paulo and Recife ${ }^{19}$. Seroepidemiology in patients of northern Brazil identified Hantaan IgG and IgM in $8.4 \%$ to $1.9 \%$. In São Paulo, in 1976, 1.2\% of patients admitted presented Hantaan $\operatorname{IgM}^{19}$.In 1993, between November and December, three individuals living in rural area of Juquitiba, $\mathrm{SP}^{7}$, became ill and from these cases, the importance of intensive epidemiological studies of hantaviruses in Brazil became apparent. Since then, HPS has been observed in all regions of the country; however, most known cases of HPS occurred in the south and southeast of Brazil, where studies conducted in different periods showed volunteer prevalence in these regions.

The seroprevalence in this study falls within the expected profile of areas with confirmed cases of hantavirus infection, as shown by previous studies ${ }^{7,19-22}$. However, this finding contradicts the epidemiological situation for hantaviruses, which according to the Brazilian Ministry of Health, is considered harmless for hantavirus. In the region studied, the overall prevalence of anti-hantavirus antibodies among rural and peri-urban residents was 3.5\%, with higher prevalence among women, who represented $58.3 \%$ of the total number of positive cases. Another study showing seroprevalence of 
0.7\% in the City of Jardinópolis, State of São Paulo, verified that contact occurred irrespective of genus, profession or history of contact with rodents, indicating that many people had been exposed to hantavirus and had presented severe clinical symptoms ${ }^{7}$. However, all the positive samples in this work were rural workers. This finding is similar to a serum prevalence study conducted in Colombia, where all positive samples came from men involved in agricultural activities ${ }^{23}$.

Other serological surveys in Latin America, show the presence of antibodies against hantavirus in previously healthy populations, with no significant differences between sex or age. Prevalence in Venezuela was $1.7 \%^{24}$; in northeastern Argentina, seroprevalence was $6.5 \%$ and was statistically significant for rural activity compared to other studies ${ }^{25}$; while Chile showed a seroprevalence of $1.9 \%$ among family members of patients with HPS ${ }^{25-27}$. The highest prevalence occurred in Paraguay, with a mean of $42.7 \%$, and the risk of infection was higher among those who lived in rural environments, similar to the present study ${ }^{21,27}$.

Two hypotheses are proposed to explain these striking differences between the epidemiology of countries and regions, as well as different areas of a particular country: I) the circulation of distinct hantavirus strains, some of which are less virulent; and II) the existence of two coincident variables, the nature of exposure and the genetic constitution of the host. In the second case, increased strength of the local population could be associated with greater exposure to the virus in some regions, but it is unclear how ethnicity might play a role or interact with environmental factors of exposure ${ }^{27-29}$.

The probable contact with hantavirus, reported by respondents, may simply involve the procedure of sweeping or raking barns and sheds, causing the suspension of aerosols containing rodent excreta and the aspiration of viral particles in the air ${ }^{7,13}$; this is the likely form of infection, especially in women, who are primarily responsible for this task and who presented $58.3 \%$ of reactive sera in the present study; in contrast, $41.7 \%$ of positive samples were from men, who are primarily responsible for planting and harvesting. The practice of storing food in barns suggests that the infection occurs around the home, since the abundance of food would attract a large population of rodents to the peridomicile area ${ }^{3}$.

Among seroreactive individuals, $91 \%$ were farm workers, who are considered by other studies to be the largest population at risk ${ }^{30}$. One serum sample that was reactive was collected from a young student who assisted his parents with the agricultural activities. Similar to that previously reported, all were involved in the practice of storing food in barns and sheds ${ }^{31}$. The infection probably occurred close to home or during manual work planting corn in a place abundant with rodents; this is due to both the wider choice of food during planting and the provision of natural forest and Araucaria pines ${ }^{13}$.

The antibody titers are of some interest, particularly when taking into account that the antibody levels verified in these individuals could be due to contact with hantavirus that may have occurred many years ago. Despite the severity of HPS, cases of human infection with hantavirus that produce mild disease without respiratory failure do occur; however the causes and factors involved in clinical behavior remain unknown ${ }^{9}$. These cases are proven by the presence of hantavirus antibodies in the general population, detected in serological surveys that include people with no history of HPS: in regions of Paraguay, 40\%; Salta Province in Argentina, 17\%; and the City of Jardinópolis in São Paulo, 14.3\% ${ }^{7}$. In other similar works, the highest titers were $1: 400$ and $1: 3200^{7,21}$.
Among the studies conducted on rodents in the vicinity of the region, reports of the transmission of hantavirus in southern Brazil indicate that the Araraquara virus is associated with N. lasiurus, while the Juquitiba virus is associated with $O$. nigripes ${ }^{17}$. The presence of these rodents in the region suggests that the viruses circulating in this area are Araraquara and Juquitiba.

Each hantavirus is primarily associated with a specific rodent host in a particular geographic region, but occasional transmissions can occur sporadically among rodents ${ }^{33-36}$. Conclusive evidence that the virus studied can establish productive infections in more than one species of rodent host has not been established. We suggest Araraquara and Juquitiba as possible viruses circulating in this study area, based on the geographical distribution of these viruses and the assumption that no other strain is in circulation. However, the possibility of an unknown hantavirus or one not yet reported in Brazil ${ }^{31,32}$, or even a hantavirus previously reported in Argentina, given the proximity of this region with the neighboring country, cannot be discarded.

The present findings suggest that in the far west of the State of Santa Catarina, hantavirus is in circulation, even though it is considered harmless by the Ministry of Health. Considering that Argentina is an endemic location for hantavirus, in particular the Province of Misiones, which borders the area under study, further studies should be conducted to assess which virus is circulating in the region and rodents involved in its transmission, since the border in this region is only a geopolitical issue and not a physical barrier.

\section{ACKNOWLEDGMENTS}

The authors would like to thank the towns of Paraíso and Belmonte for their contribution to the fieldwork and technician Neusa Salete Fiorini and biomedic Evanio Junior Wronski for their assistance during the sample collection procedures and interviews. The authors are also grateful to the Center for Research in Virology, FMRP-USP, Ribeirão Preto, for their support in the analysis.

\section{CONFLICT OF INTEREST}

The authors declare that there is no conflict of interest.

\section{REFERENCES}

1. Jonsson CB, Hooper J, Mertz G. Treatment of hantavirus pulmonary syndrome. Antiviral Res 2008; 78:162-169.

2. Zeier M, Handermann M, Bahr U, Rensch B, Muller S, Kehm R, et al. New ecological aspects of hantavirus infection: a change of a paradigm and a challenge of prevention-a review. Vir Gen 2005; 30:157-180

3. Easterbrook JD, Klein SL. Immunological Mechanisms Mediating Hantavirus Persistence in Rodent Reservoirs. PLoS Pathog 2008; 4:11.

4. Wells RM, Sosa Stani S, Yadón Z, Enria D, Padula P, Pini N, et al. An unusual hantavirus outbreak in southern Argentina: person-to-person transmission? Emerg Infect Dis 1997; 3:171-174.

5. Padula PJ, Edelstein A, Miguel SD, Lopez NM, Rossi CM, Rabinovich RD Hantavirus pulmonary syndrome outbreak in Argentina: Molecular evidence for person-to-person transmission of Andes virus. Virology 1998; 241:323-330.

6. Martinez VP, Bellomo C, San Juan J, Pinna D, Forlenza R, Elder M, et al. Personto-person transmission of Andes virus. Emerg Infect Dis 2005; 11:1848-1853.

7. Campos GM, Sousa RL, Badra SJ, Pane C, Gomes UA, Figueiredo LT. Serological survey of hantavirus infection in Jardinopolis County, Brazil. J Med Virol 2003; 71:417-422. 
8. Mori M, Rothman AL, Kurane I, Montoya JM, Nolte KB, Norman JE, et al High levels of cytokine- producing cells in the lung tissues of patients with fatal hantavirus pulmonary syndrome. J Infect Dis 1999; 179:295-302.

9. Mertz GJ. Bunyaviridae: Bunyaviruses, phleboviruses, nairoviruses, and hantaviruses. In: Richmann DD, Whitley RJ, Hayden FG, editors. Clinical virology. $2^{\text {nd }}$ Ed. New York: Churchill-livinsgstone; 1997. p. 943-972.

10. Machado AM, Figueiredo GG, Sabino GSJ, Figueiredo LTM. Laboratory diagnosis of human hantavirus infection: novel insights and future potential. Future Virol 2009; 4:383-389.

11. Figueiredo LTM, Moreli ML, Borges AA, Figueiredo GG, Bisordi I, Suzuki A, et al. Evaluation of an Enzyme-Linked Immunosorbent Assay Based on Araraquara Virus Recombinant Nucleocapsid Protein. Am J Trop Med Hyg 2009; 81:273-276

12. Padula PJ, Colavecchia SB, Martinez VP, Gonzalez Della Valle MO, Edelstein A, Miguel SDL, et al. Genetic diversity, distribution, and serological features of hantavirus infection in five countries in South America. J Clin Microbiol 2000; 38:3029-3035

13. Figueiredo LTM, Moreli ML, Souza LM, Borges AA, Figueiredo GG, Machado $\mathrm{AM}$, et al. Hantavirus pulmonary syndrome, Central Plateau, Southeastern, and Southern Brazil. Emerg Infect Dis 2009; 15:561-567.

14. Raboni SM, Rubio G, De Borba L, Zeferino A, Skraba SG, Santos CND. Clinical survey of hantavirus in southern Brazil and the development of specific molecular diagnosis tools. Am J Trop Med Hyg 2005; 72:800-804.

15. Figueiredo LTM, Moreli ML, Borges AA, Figueiredo GG, Souza RLM, Aquino VH Expression of a hantavirus $\mathrm{N}$ protein and its efficacy as antigen in immune assays. Braz J Med Biol Res 2008; 41:596-599.

16. Ministério da Saúde. Ministério da Saúde Web Site [Internet]. [Cited 2010 Feb 8]. Available from: http://portal.saude.gov.br/portal/saude/Gestor/ visualizar_texto.cfm?idtxt $=27673 /$.

17. Suzuki A, Bisordi I, Levis S, Garcia J, Pereira LE, Souza RP, et al. Identifying rodent hantavirus reservoirs. Brazil. Emerg Infect Dis 2004; 10:2127-2134.

18. Padula P, Martinez VP, Bellomo C, Maidana S, San Juan J, Tagliaferri P, et al Pathogenic Hantaviruses, Northeastern Argentina and Eastern Paraguay. Emerg Infect Dis 2007; 13:1211-1214.

19. Leduc JW, Smith GA, Pinheiro FP, Vasconcelos PFC, Rosa EST, Maiztegui JI. Isolation of a hantaan-.related virus from brazilian rats and serologic evidence of its widespread distribution in south america. Am J Trop Med Hyg 1985; 34:810-815

20. Iversson LB. Doença humana por hantavirus. In: Veronesi R, Focaccia R, editores. Tratado de infectologia. $1^{\text {st }}$ Ed. São Paulo: Atheneu; 1996. p. 219-228.

21. Pereira GW, Teixeira AM, Souza MS, Pereira TSS, Braga AD, Santos Junior GS et al. Inquérito sorológico e de morbidade para hantavírus na população rural e periurbana da cidade de Turvo, SC. Jornada Unisul de Iniciação Científica 2009; 1-6.

22. Holmes R, Boccanera R, Figueiredo LT, Mançano SR, Pane C. Seroprevalence of human hantavirus infection in the Ribeirao Preto region of Sao Paulo State, Brazil. Emerg Infect Dis 2000; 6:560-561.

23. Máttar S, Parra M. Serologic evidence of hantavirus infection in humans, Colombia. Emerg Infect Dis 2004; 10:2263-2264.

24. Rivas YJ, Moros Z, Moron D, Uzcategui MG, Duran Z, Pujol FH, et al. The seroprevalences of anti-hantavirus IgG antibodies among selected Venezuelan populations. Ann Trop Med Parasitol 2003; 97:61-67.

25. Pini N, Levis S, Calderón G, Ramirez J, Bravo D, Lozano E, et al.. Hantavirus infection in humans and rodents, northwestern Argentina. Emerg Infect Dis 2003; 9:1070-1076.

26. Castillo C, Villagra E, Sanhueza L, Ferres M, Mardones J, Mertz GJ. Prevalence of antibodies to hantavirus among family and health care worker contacts of persons with hantavirus cardiopulmonary syndrome: lack of evidence for nosocomial transmission of Andes virus to health care workers in Chile. Am J Trop Med Hyg 2004; 70:302-304

27. Pini N. Hantavirus pulmonary syndrome in Latin America. Curr Opin Infect Dis 2004; 17:427-431

28. Ferres M, Vial P. Hantavirus infection in children. Curr Opin Pediatr 2004; 16:70-75
29. Täger Frey MT, Vial PC, Castillo CH, Godoy PM, Hjelle B, Ferrés MG. Hantavirus prevalence in the IX Region of Chile. Emerg Infect Dis 2003; 9:827-832.

30. Figueiredo LTM, Moreli ML, Campos GM, Sousa RL. Hantaviruses in São Paulo State, Brazil. Emerg Infect Dis 2003; 9:891-892

31. Mendes WS, Aragão NJL, Santos HJ, Raposo L, Vasconcelos PFC, Rosa EST, et al. Hantavirus pulmonary syndrome in Anajatuba, Maranhão, Brazil. Rev Inst Med Trop Sao Paulo 2001; 43:237-240.

32. Johnson AM, Souza LTM, Ferreira IB, Pereira LE, Ksiazek TG, Rollin PE, et al. Genetic investigation of novel hantaviruses causing fatal HPS in Brazil. J Med Virol 1999; 59:527-535.

33. Rosa ES, Mills JN, Padula PJ, Elkhoury MR, Ksiazek TG, Mendes WS, et al Newly recognized hantaviruses associated with hantavirus pulmonary syndrome in northern Brazil: partial genetic characterization of viruses and serologic implication of likely reservoirs. Vect Born Zoon Dis 2005; 5: 11-19.

34. Plyusnin A, Morzunov SP. Virus evolution and genetic diversity of hantaviruses and their rodent hosts. Curr Top Microbiol Immunol 2001; 256:47-75.

35. Ramsden C, Melo FL, Figueiredo LM, Holmes EC, Zanotto PM, VGDN Consortium. High rates of molecular evolution in hantaviruses. Mol Biol Evol 2008; 25:1488-1492.

36. Chu YK, Milligan B, Owen RD, Goodin DG, Jonsson CB. Phylogenetic and geographical relationships of hantavirus strains in eastern and western Paraguay. Am J Trop Med Hyg 2006; 75:1127-1134. 